\title{
EVIDENCE INFORMED POLICY PADA PROGRAM TIKET ONLINE TAMAN SATWA KEBUN BINATANG SURABAYA
}

\author{
${ }^{1}$ Inka Mustika Sari, ${ }^{2}$ Arimurti Kriswibowo \\ 1,2 Program Studi Administrasi Publik Fakultas IImu Sosial dan IImu Politik \\ Universitas Pembangunan Nasional "Veteran" Jawa Timur \\ mustikasariinka@gmail.com , arimurti.adne@upnjatim.ac.id
}

\begin{abstract}
Surabaya Zoo Animal Park is one of the tourist attractions in the city of Surabaya with increasing visitors every year. Currently, during the pandemic, the Surabaya Zoo's Animal Park has used a new innovation, namely a policy in the form of an online tourist admission ticket program. This has resulted in a decrease in the number of visitors at the Surabaya Zoo's Animal Park. This study aims to determine how evidende informed policy is in the online ticketing program at the Surabaya Zoo's Animal Park. The type of research used in this article is to use a qualitative approach. The results showed that the process of evidence informed policy has been implemented but there are still many people or visitors who do not understand this program. The conclusion of this research is that the process of evidence informed policy that occurs is not yet optimal, this can be seen from the indicators of evidence informed policy.
\end{abstract}

Keywords: Evidence Informed Policy; Online Tickets; Tourist park; Zoo

\begin{abstract}
Abstrak
Taman Satwa Kebun Binatang Surabaya sebagai salah satu wisata di Kota Surabaya dengan pengunjung yang meningkat disetiap tahunnya. Saat ini, pada masa pandemi Taman Satwa Kebun Binatang Surabaya telah menggunakan inovasi baru yaitu kebijakan berupa program tiket masuk wisata secara online. Hal ini mengakibatkan turunnya jumlah pengunjung di Taman Satwa Kebun Binatang Surabaya. Penelitian ini bertujuan untuk mengetahui bagaimana evidende informed policy pada program tiket online di Taman Satwa Kebun Binatang Surabaya. Jenis penelitian yang digunakan dalam artikel ini adalah dengan menggunakan pendekatan kualitatif. Hasil penelitian menunjukkan bahwa proses evidence informed policy telah dilaksanakan tetapi masih banyak masyarakat atau pengunjung yang kurang memahami tentang program ini. Kesimpulan dari penelitian ini adalah proses evidence informed policy yang terjadi belum optimal, hal ini dapat dilihat dari indikatorindikator evidence informed policy.
\end{abstract}

Keywords: Evidence Informed Policy; Kebun binatang; Taman wisata; Tiket Online

Open Access at:http://ojs.uho.ac.id/index.php/PUBLICUHO/index

Journal Publicuho is licensed under a Creative Commons Attribution 4.0 International License.

\section{PENDAHULUAN}

Sejak kemunculan COVID-19 pada awal tahun 2020 di Indonesia membawa dampak dan pengaruh besar khususnya pada sektor perekonomian, dimana melumpuhnya beberapa kegiatan ekonomi seperti produksi dan jasa, tutupnya beberapa sektor ekonomi baik wisata, rumah makan, penginapan guna mengurangi rantai penyebaran. Kota Surabaya kini memasuki masa transisi ke new normal, dimana hal ini merupakan tatanan baru yang mengharuskan masyarakat menjaga produktivitas di tengah pandemi COVID-19. 


\section{Journal Publicuho}

ISSN2621-1351 (online), ISSN 2685-0729 (print)

Volume 4 Number 2 (May-July), (2021)pp. 360-370

Accredited SINTA SK.NOMOR 28/E/KPT/2019

Open Access at:http://ojs.uho.ac.id/index.php/PUBLICUHO/index

DOI: 10.35817/jpu.v4i2.17957

Kata lain dari new normal yaitu Adaptasi Kebiasaan Baru (AKB). Mengingat pentingnya meningkatkan produktivitas dalam berbagai sektor kehidupan masyarakat, baik itu di sektor ekonomi, politik, maupun budaya dengan berbagai program kerja kebijakan nasional. Meningkatkan produktivitas masih bisa dilakukan dengan selalu membudayakan perilaku hidup bersih dan sehat. Adanya new normal ini diharapkan dapat bertujuan untuk mengatasi dan menstabilkan perekonomian daerah tersebut akibat COVID-19 dalam sektor pariwisata, perdagangan industri, maupun transportasi.

Dalam hal ini sektor pariwisata adalah salah satu sektor yang dapat mengatasi masalah perekonomian. Sektor pariwisata adalah sektor yang potensial untuk dikembangkan sebagai salah satu sumber pendapatan daerah. Sektor pariwisata juga berpengaruh terhadap perekonomian di Indonesia, termasuk Kota Surabaya. Pariwisata merupakan bagian yang tidak terpisahkan dari kehidupan manusia terutama dalam kegiatan sosial dan ekonomi, dalam menghadapi tantangan dan peluang telah dilakukan perubahan peran pemerintah dibidang kebudayaan dan pariwisata yang pada masa lalu berperan sebagai pelaksana pembangunan, saat ini lebih difokuskan hanya kepada tugastugas pemerintahan terutama sebagai fasilitator agar kegiatan pariwisata yang dilakukan dapat berkembang dengan pesat (Sukirno, 2006).

Pariwisata merupakan suatu cara untuk memenuhi kebutuhan manusia dalam memberikan hiburan untuk diri sendiri setelah beberapa waktu yang dihabiskan dalam kesibukan untuk berwisata. Banyaknya aktivitas dan tingginya tuntutan hidup membuat kebutuhan masyarakat untuk rekreasi dan hiburan semakin meningkat. Perubahan perilaku dan cara pandang yang mulai berkembang dengan menjadikan rekreasi sebagai kebutuhan hidup mereka dan rekreasi yang dimaksud yaitu dengan mengunjungi tempat wisata yang merupakan suatu destinasi (Roihanah, 2017).

Berdasarkan Surat Keputusan Badan Nasional Penanggulangan Bencana Republik Indonesia tentang Perpanjangan Status Darurat Bencana COVID-19 maka juga berdampak pada sektor pariwisata. Dengan adanya pandemi COVID-19 yang berdampak pada sektor pariwisata ini mengakibatkan tempat wisata yang ada di Kota Surabaya harus tutup sementara. Hal tersebut dilakukan untuk mengantisipasi atau pencegahan persebaran COVID-19. Ditutupnya tempat wisata ini menyebabkan tidak adanya tempat untuk edukasi pembelajaran diluar sekolah, dan seluruh manusia kehilangan kebutuhannya untuk rekreasi dan mendapatkan hiburan.

Salah satu sektor pariwisata di Kota Surabaya yang terkena dampak dari adanya COVID-19 yaitu Taman Satwa Kebun Binatang Surabaya. Pada tahun 2014 kepengurusan Kebun Binatang Surabaya diambil alih oleh Pemerintah Kota Surabaya, karena setahun 
terakhir sebelum kepengurusan diambil alih oleh pemerintah kota, banyak satwa yang mati dan kurang terurus dengan baik.

Tabel 1. Jumlah Pengunjung PDTS Kebun Binatang Surabaya Tahun 2016-2019

\begin{tabular}{cc}
\hline Tahun & Pengunjung \\
\hline 2016 & 1.360 .000 orang \\
\hline 2017 & 1.571 .000 orang \\
\hline 2018 & 2.010 .000 orang \\
\hline 2019 & 2.500 .000 orang \\
\hline
\end{tabular}

Sumber: Surabaya Zoo, PDTS KBS (2019)

Pada tabel tersebut dapat diketahui bahwa tingkat kunjungan Kebun Binatang Surabaya sebelum terjadinya pandemi COVID-19 mengalami rata-rata peningkatan pada setiap tahunnya. Pada masa transisi adaptasi kebiasaan baru ini tentunya akan ada perubahan-perubahan atau kebijakan baru yang telah dibuat oleh pihak Perusahaan Daerah Taman Satwa Kebun Binatang Surabaya dan Pemerintah Kota Surabaya setelah ditutup akibat adanya COVID-19 berdasarkan Peraturan Wali Kota (Perwali) Surabaya No. 28 Tahun 2020 tentang Pedoman Tatanan New Normal Baru Pada Kondisi Pandemi COVID-19 Bagian Kesepuluh Kegiatan Di Tempat Hiburan dan Pariwisata. Kebijakan baru dibuat tentunya dengan tujuan dapat memberikan pelayanan yang terbaik, maksimal, dan tetap menggunakan protokol kesehatan. Penerapan protokol kesehatan yang dilakukan oleh Kebun Binatang Surabaya yaitu pengunjung wajib menggunkan masker, kursi pengunjung di area Kebun Binatang Surabaya berjarak, atur alur pengunjung selama dia area Kebun Binatang Surabaya, kapasitas pengunjung dalam sehari dibatasi, durasi kunjungan juga dibatasi, dan pembelian tiket dapat dilakukan secara online.

Dalam hal ini kehadiran teknologi sangat berperan penting dalam mempermudah kehidupan pada masa adaptasi kebiasaan baru dalam berbagai hal. Pengembangan teknologi di Kota Surabaya didukung dengan Peraturan Wali Kota (Perwali) Surabaya No. 5 Tahun 2013 tentang Pedoman Pemanfaatan Teknologi Informasi dan Komunikasi Dalam Penyelenggaraan Pemerintah Daerah, dimana dalam butir pertama disebutkan bahwa pemanfaatan teknologi informasi dan komunikasi yang memadai diperlukan guna mengoptimalkan kinerja aparatur Pemerintah Kota Surabaya dalam rangka penyelenggaraan pemerintah serta memberi pelayanan kepada masyarakat.

Kebun Binatang Surabaya kembali dibuka untuk umum setelah selama empat bulan ditutup akibat adanya pandemi COVID-19. Pihak dari Kebun Binatang Surabaya telah mencoba untuk memanfaatkan teknologi dengan membuat kebijakan yaitu pembelian tiket masuk Kebun Binatang Surabaya yang dilakukan secara online. Hal ini diketahui dari berbagai macam pemberitaan di media online seperti pada Humas.surabaya.go.id dari berita tersebut dapat dimaknai bahwa pembukaan wisata Taman Satwa Kebun Binatang 


\section{Journal Publicuho}

ISSN2621-1351 (online), ISSN 2685-0729 (print)

Volume 4 Number 2 (May-July), (2021)pp. 360-370

Accredited SINTA SK.NOMOR 28/E/KPT/2019

Open Access at:http://ojs.uho.ac.id/index.php/PUBLICUHO/index

DOI: 10.35817/jpu.v4i2.17957

Surabaya ini merupakan adaptasi untuk warga dan membantu Pemerintah Kota Surabaya dalam memberikan edukasi pada masyarakat terkait tata cara berkunjung ke destinasi wisata pada masa pandemi COVID-19.

Tidak hanya sebagai salah satu upaya dalam pencegahan penyebaran COVID-19, kebijakan pembelian tiket online ini dapat membantu pengunjung untuk melakukan pemesanan tiket masuk Kebun Binatang Surabaya secara online melalui internet di mana saja dan kapan saja sehingga calon pengunjung tidak perlu datang langsung ke tempat wisata dan menghabiskan waktu untuk mengantri. Hal tersebut juga dikemukakan oleh (Ibrahim, 2011) jika pembelian tiket secara online maka informasi mengenai jadwal dapat dilakukan secara online, dan memberi kemudahan bagi masyarakat yang ingin melakukan pemesanan tiket di manapun berada, menghemat waktu dan bisa dilakukan kapan saja.

Gambar 1. Data Jumlah Pengunjung PDTS Kebun Binatang Surabaya Pada Bulan Januari Sampai September Tahun 2020

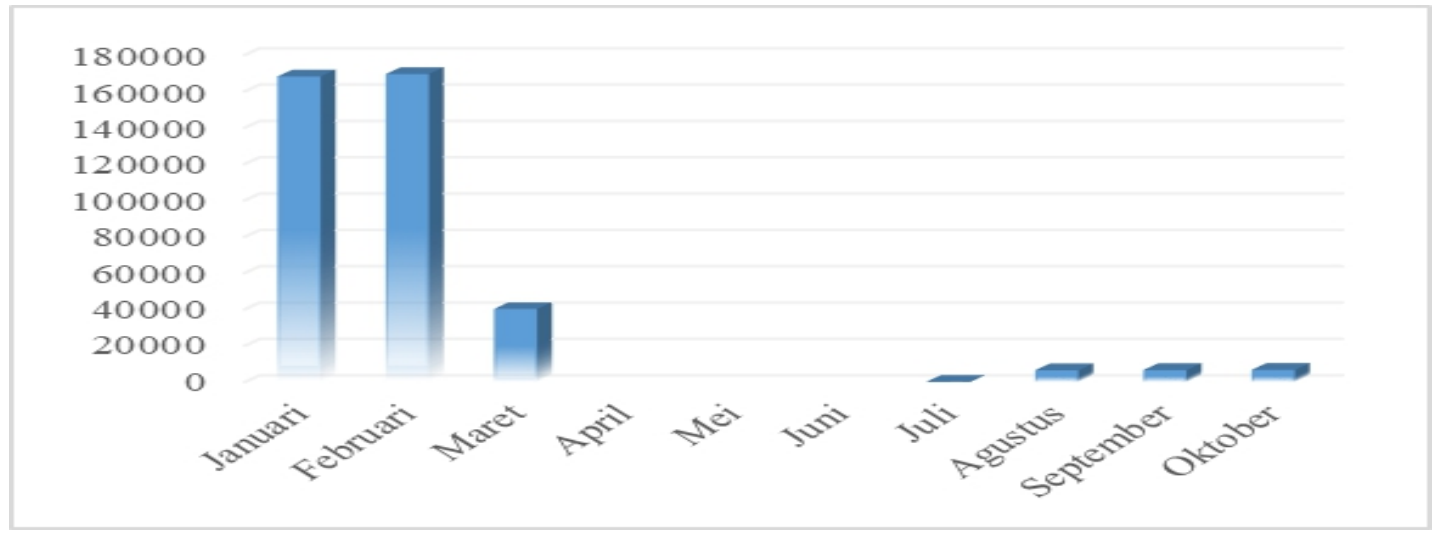

Sumber: Surabaya Zoo, PDTS KBS (2020)

Jika dilihat dari grafik diatas, Pada Bulan Juli, tempat wisata PDTS Kebun Binatang Surabaya dibuka kembali, tetapi tidak banyak pengunjung yang datang ke tempat wisata tersebut. Hal ini dikarenakan setelah ditutupnya PDTS Kebun Binatang Surabaya ada banyak perubahan yang dilakukan oleh pihak PDTS Kebun Binatang Surabaya mulai dari pembelian tiket sampai dengan pembatasan waktu kunjungan dan pembatasan kuota pengunjung.

Turunnya jumlah pengunjung di Perusahaan Daerah Taman Satwa Kebun Binatang Surabaya juga karena banyak masyarakat yang belum tahu mengenai tiket masuk wisata yang harus dibeli secara online. Hal ini juga diketahui dari pemberitaan media online seperti pada Jawapos.com dari berita ini dapat dimaknai bahwa Kebijakan ini dianggap sejumlah pengunjung merasa dipersulit oleh pihak PDTS Kebun Binatang Surabaya dalam memasuki wisata untuk berekreasi dan memenuhi kebutuhan dengan memberikan hiburan untuk diri sendiri maupun keluarga. Padahal kebijakan ini dibuat dengan tujuan untuk memudahkan masyarakat dalam pembelian tiket masuk Kebun Binatang Surabaya yang dapat dilakukan 
dimanapun dan kapanpun. Serta dengan adanya kebijakan yang telah dibuat dapat menekan atau pencegahan persebaran COVID-19.

Perlu adanya bukti informasi untuk mengetahui apakah PDTS Kebun Binatang Surabaya juga melibatkan pemangku kepentingan dalam proses pelaksanaan kebijakan pada program tiket online. Bukti informasi dari kebijakan tersebut dapat dilakukan dengan menggunakan teori Evidence Informed Policy. Teori analisis kebijakan mengusulkan bahwa evidence informed adalah informasi yang mempengaruhi keyakinan orang-orang penting yang ada tentang fitur penting dari masalah yang diteliti dan bagaimana hal itu dapat diselesaikan atau dikurangi (Bowen S, 2005). Cara menggabungkan evidence informed penelitian dengan bentuk informasi lain yaitu kunci untuk memahami makna dan penggunaan bukti dalam pengembangan dan praktik kebijakan. Ada juga kendala, yang akan membatasi sejauh mana bukti dapat memengaruhi kebijakan yaitu tekanan untuk memproses informasi dengan cepat (ODI, 2004).

Menurut Shaxson (2005:102) evidene informed policy dibutuhkan untuk memahami lingkungan kebijakan dan bagaimana perubahannya, menilai dampak yang mungkin timbul dari perubahan kebijakan sehingga dapat memilih di antara opsi kebijakan yang berbeda dan kemudian menilai dampaknya, menunjukkan hubungan antara arah strategis, hasil yang diharapkan dan tujuan kebijakan, untuk menunjukkan bahwa ada garis argumen dan bukti yang jelas antara apa yang kita tuju dan apa yang dilakukan sekarang, menentukan apa yang perlu dilakukan untuk memenuhi tujuan strategis atau tujuan menengah, mempengaruhi orang lain sehingga mereka dapat membantu mencapai tujuan kebijakan dan membawanya hingga mencapai tujuan.

Menurut Thomas R Dye (dalam Wayne Parsons, 2005: xi) yang dilkutip dari (Elwan, L.O.M, 2011:15). "public policy is whatever governments choose to do or not to do" kebijakan publik sebagai "apapun pilihan pemerintah untuk melakukan atau tidak melakukan. Dalam upaya mencapai tujuan negara, pemerintah perlu mengambil pilihan tindakan yang dapat berupa melakukan sesuatu atau tidak melakukan sesuatu. Keduanya, menurut definisi Dye, merupakan kebijakan publik karena merupakan upaya mencapai tujuan tertentu dan keduanya memiliki dampak terhadap masyarakat (Supriadin, Alam, \& Elwan, 2020)

Demikian halnya menurut Jones (1991) dalam La Ode Muhammad Elwan, (2011: 18) menjelaskan bahwa Implementasi kebijakan mudah dimengerti secara teoritik dan konseptual, namun tidak senantiasa demikian dalam bentuknya yang kongkrit, karena pelaksanaannya secara nyata bukanlah sesuatu yang mudah (Supriadin et al., 2020)

Implementasi menghadapi tantangan teknis dan politik dalam menginformasikan kebijakan saat menangani penyampaian program, layanan dan alat yang inovatif (Panisset, 2012). Pada tahap ini, pengembangan program tiket online di Kebun Binatang Surabaya, menempatkan pemangku kepentingan pada risiko yang besar. Dengan demikian, sejumlah 


\section{Journal Publicuho}

ISSN2621-1351 (online), ISSN 2685-0729 (print)

Volume 4 Number 2 (May-July), (2021)pp. 360-370

Accredited SINTA SK.NOMOR 28/E/KPT/2019

Open Access at:http://ojs.uho.ac.id/index.php/PUBLICUHO/index

DOI: 10.35817/jpu.v4i2.17957

besar pemangku kepentingan akan mendukung penerapan kebijakan tersebut, meskipun mereka belum tentu menyetujui kelayakan manfaat yang diharapkan. Pelaksanaan suatu kebijakan juga dapat menghadapi oposisi di berbagai titik keputusan. Penelitian implementasi dapat memberikan bukti untuk mendukung atau menyangkal dasar penentangan atau dukungan. Oleh karena itu, para pemangku kepentingan akan menafsirkan bukti dari penelitian implementasi dengan menggunakan indikator awareness, adoption, implementation, dan maintenance. Selanjutnya, peneliti ingin mengisi kekosongan penelitian yang belum pernah dilakukan sebelumnya. Sehingga penelitian ini bertujuan untuk mengetahui bagaimana evidence informed policy pada program tiket online di PDTS Kebun Binatang Surabaya.

\section{METODOLOGI}

Jenis penelitian yang digunakan dalam artikel ini adalah dengan menggunakan pendekatan kualitatif deskriptif dengan maksud memberi gambaran komprehensif, masukan dan rekomendasi kepada stakeholder yang terlibat pada pelaksanaan program tiket online di PDTS Kebun Binatang Surabaya. Penelitian kualitatif atau naturalistic inquiry adalah prosedur penelitian yang menghasilkan data deskriptif berupa kata-kata tertulis atau lisan dari orang-orang dan perilaku yang dapat diamati (Suharsaputra, 2018). Pendapat lain (Sugiyono, 2018) mengatakan metode penelitian kualitatif adalah metode penelitian yang berdasarkan pada filsafat positivisme, digunakan untuk meneliti pada obyek yang alamiah dimana peneliti adalah sebagai instrument kunci. Teknik pengumpulan data dalam penelitian ini menggunakan observasi terusterang atau tersamar, wawancara terstruktur, dan dokumentasi yang akan diambil yaitu berbentuk arsip dokumen, rekaman, dan foto kegiatan.Informan dalam penelitian ini dipilih dengan menggunakan teknik purposive atau teknik penentuan informan berdasarkan pertimbangan tertentu yang terdiri dari Humas PDTS KBS dan Masyarakat dengan kategori pengunjung dewasa atau pembeli tiket masuk di PDTS KBS secara online. Teknik analisis data dalam penelitian ini dengan menggunakan 4 alur, yaitu pengumpulan data, kondensasi data, penyajian data, penarikan kesimpulan, dan untuk keabsahan data menggunakan triangulasi teknik.

\section{HASIL DAN PEMBAHASAN}

Salah satu kebijakan baru yang dijalankan oleh Taman Satwa Kebun Binatang Surabaya yaitu program tiket masuk wisata secara online. Tujuan dari adanya program tiket online ini, untuk memudahkan masyarakat dalam pembelian tiket masuk Kebun Binatang Surabaya yang dapat dilakukan dimanapun dan kapanpun. Serta dengan adanya kebijakan berupa program tiket online yang telah dijalankan dapat menekan atau pencegahan persebaran COVID-19. 
Dalam hal ini peneliti ingin mengetahui apakah ada bukti informasi keterlibatan pemangku kepentingan dalam pembuatan program tiket online ini. Bukti informasi dari kebijakan tersebut dapat dilakukan dengan menggunakan teori Evidence Informed Policy. Teori tersebut mempunyai 4 indikator yaitu awareness, adoption, implementation, dan maintenance. Berdasarkan hasil yang peneliti temukan dilapangan dan didasarkan pada teori evidence informed policy dalam (Strehlenert, 2015) antara lain:

\section{Awareness (Kesadaran)}

Kesadaran yaitu proses yang digambarkan sebagai interaksi kompleks dari proses top-down dan bottom-up antara badan pemerintah dan organisasi publik. Model pedoman menyiratkan strategi aktif untuk meningkatkan kesadaran dengan melibatkan pemangku kepentingan selama pengembangan pedoman. Tujuannya adalah untuk mendapatkan dukungan dari para pelaku profesional dan dengan demikian meningkatkan peluang penerimaan positif di antara khalayak sasaran (Strehlenert, 2015).

Taman Satwa Kebun Binatang Surabaya memiliki tanggung jawab formal untuk meningkatkan kesadaran, dan komunikasi strategis. Awalnya, penekanan besar diberikan untuk menjangkau informasi dengan cepat. Taman Satwa Kebun Binatang Surabaya melibatkan pemangku kepentingan dan juga menggunakan jaringan mereka untuk menyebarkan kebijakan tersebut yaitu program tiket online. Dalam hal ini pemangku kepentingan yang terlibat dalam pembuatan kebijakan program tiket online yaitu Pemerintah Kota Surabaya. Pemerintah dan Taman Satwa Kebun Binatang Surabaya bekerja sama untuk meningkatkan kesadaran khalayak sasaran. Khalayak sasaran yang dimaksud yaitu masyarakat atau pengunjung wisata.

Untuk meningkatkan kesadaran khalayak sasaran atau masyarakat terkait program tiket online ini, interaksi Pemerintah dan Taman Satwa Kebun Binatang kepada masyarakat juga dilakukan secara online dengan menggunakan web resmi dari Taman Satwa Kebun Binatang Surabaya. Dalam masa pandemi, interaksi yang dilakukan secara online seperti ini dapat membantu dalam mencegah persebaran COVID-19. Interaksi secara online juga bisa dikatakan dapat menghemat waktu dan biaya, karena dapat diakses kapanpun dan dimanapun.

Akan tetapi tidak banyak masyarakat yang mengetahui akan adanya interaksi yang dilakukan oleh Pemerintah dan Taman Satwa Kebun Binatang Surabaya. Hal ini dikarenakan interaksi tersebut hanya dilakukan secara online saja. Jadi, hanya masyarakat dengan kesadarannya membuka web resmi Taman Satwa Kebun Binatang Surabaya yang dapat mengetahui akan adanya interaksi tersebut.

\section{Adoption (Adopsi)}

Adanya penawaran dana kepada organisasi profesional untuk meluncurkan proyek implementasi dan kepada para peneliti, yang bertujuan untuk meningkatkan 


\section{Journal Publicuho}

ISSN2621-1351 (online), ISSN 2685-0729 (print)

Volume 4 Number 2 (May-July), (2021)pp. 360-370

Accredited SINTA SK.NOMOR 28/E/KPT/2019

Open Access at:http://ojs.uho.ac.id/index.php/PUBLICUHO/index DOI: 10.35817/jpu.v4i2.17957

pengetahuan tentang bagaimana pedoman dapat diadopsi. Penerapan kebijakan digambarkan sebagai kompleks dan lambat, tetapi sebagai proses yang berpotensi menjanjikan. Menurut Trachtman (2020) adopsi kebijakan perlu memperhatikan politik kebijakan atau interaksi antara pembuat kebijakan dan masyarakat, mengingat karena adanya tekanan dari masyarakat kepada pembuat kebijakan.

Taman Satwa Kebun Binatang Surabaya memberikan insentif yang kuat bagi pemangku kepentingan dan tingkatan politik yang lebih tinggi untuk mengadopsi kebijakan dalam program tiket online. Manfaat praktik berbasis bukti digunakan sebagai argumen untuk mendorong adopsi di kalangan profesional. Nilai inti dari kebijakan dalam program tiket online tersebut yaitu, manfaat bagi pengunjung wisata Taman Satwa Kebun Binatang Surabaya. Ini digambarkan sebagai pilihan strategis, karena banyaknya aktivitas dan tingginya tuntutan hidup dalam masa pandemi membuat kebutuhan masyarakat untuk rekreasi dan hiburan semakin meningkat adalah fitur yang sangat disepakati oleh semua pemangku kepentingan.

Selanjutnya, Taman Satwa Kebun Binatang Surabaya juga memberikan penawaran khusus bagi pengunjung. Penawaran tersebut sudah tersedia dalam web resmi Taman Satwa Kebun Binatang Surabaya. Beberapa penawaran yang diberikan oleh Taman Satwa Kebun Binatang Surabaya, yaitu penawaran yang pertama "Kebun Binatang Saya Keuntungan Saya", dalam penawaran ini tersedia Paket A dan Paket B, masing-masing memliki fasilitas yang berbeda. Penawaran kedua "Penjelajah Kebun Binatang", dalam penawaran ini terdapat Paket Anti Galau dan Paket Anti Corona, paket tersebut juga mempunyai syarat dan fasilitas yang berbeda-beda. Penawaran ketiga "Sensasi Edukasi Virtual", penawaran ini berbeda dengan penawaran sebelumnya, karena tidak perlu datang secara langsung ke Taman Satwa Kebun Binatang Surabaya tetapi dapat menikmati dan belajar dari rumah yang terasa nyata.

Dalam hal ini masyarakat atau pengunjung masih belum mengetahui tentang adanya penawaran-penawaran yang dibuat oleh Taman Satwa Kebun Binatang Surabaya. Pengunjung menganggap bahwa web resmi yang tersedia hanya untuk memesan tiket masuk wisata saja.

\section{Implementation (Implementasi)}

Implementasi merupakan salah satu tahap dalam proses kebijakan publik, biasanya implementasi dilaksanakan setelah sebuah kebijakan dirumuskan dengan tujuan yang jelas (Wahyudi, 2016). Adanya Sebuah kelompok manajemen inti yang mengkoordinasikan pelaksanaannya. Menganalisis informasi untuk mengidentifikasi dukungan yang dibutuhkan. Terdapat solusi yang memungkinkan dicari dan dikembangkan bersama dengan para pemangku kepentingan dan pelaku. 
Strategi fasilitatif digunakan secara luas, dengan fokus pada pembentukan struktur pendukung untuk kebijakan program tiket online tersebut. Peningkatan pembina dipekerjakan sesuai dengan bidangnya masing-masing dan Pemerintah Kota Surabaya mendukung para pembina melalui pertemuan jaringan reguler dan interaksi yang berbasis web untuk berbagi pengalaman dan informasi. Tim manajer kolaboratif dibentuk untuk mendorong implementasi dari sudut pandang manajerial. Sebuah program tiket online dimulai untuk menginspirasi tim untuk mempraktikkan rencana tindakan. Taman Satwa Kebun Binatang menciptakan arena edukasi dan berbagi pengalaman bagi tim manajemen.

Selanjutnya, mengadakan dukungan untuk untuk menganalisis data tentang tanggapan masyarakat mengenai program tiket online ini. Sebuah portal berbasis web yang dikembangkan dapat memungkinkan untuk memantau secara terbuka dan terus-menerus. Taman Satwa Kebun Binatang Surabaya menekankan komunikasi strategis dalam tahap implementasi, dan menekankan nilai setiap individu yaitu hak atas pelayanan yang mudah dan aman.

Masyarakat atau pengunjung menganggap program tiket online ini menjadi keuntungan sendiri bagi setiap pengunjung. Hal ini dikarenakan pemesanan tiket wisata yang secara online dapat dilakukan dimanapun dan kapanpun. Dengan program tiket online ini pengunjung juga tidak perlu mengantri untuk membeli tiket masuk wisata seperti tahuntahun sebelumnya.

\section{Maintenance (Pemeliharaan)}

Strategi ini menempatkan tanggung jawab untuk penegakan kebijakan berupa program yang berkelanjutan pada organisasi. Ini didasarkan pada gagasan bahwa profesi dan pembuat keputusan paling cocok untuk menilai kebutuhan dan hambatan untuk menerapkan pedoman. Adanya pertertanggungjawab untuk memperbaharui pedoman, mengulangi prosedur pengembangan dan diseminasi. Menurut Ngadiyono (2010)pemeliharaan adalah semua tindakan yang bertujuan untuk mempertahankan atau memulihkan agar dapat menjalankan fungsinya sesuai kebutuhan.

Taman Satwa Kebun Binatang Surabaya mengatur pemeliharaan alat berbasis web yang berkualitas untuk terus mendukung penggunanya. Pengukuran beberapa indikator berlanjut sebagai bagian dari pengukuran kualitas tahunan. Untuk saat ini Taman Satwa Kebun Binatang Surabaya masih memegang pedoman berdasarkan Peraturan Wali Kota (Perwali) Surabaya No. 28 Tahun 2020 tentang Pedoman Tatanan New Normal Baru pada Kondisi Pandemi COVID-19 Bagian Kesepuluh Kegiatan di Tempat Hiburan dan Pariwisata dan didukung oleh Peraturan Wali Kota (Perwali) Surabaya No. 5 Tahun 2013 tentang Pedoman Pemanfaatan Teknologi Informasi dan Komunikasi Dalam Penyelenggaraan Pemerintah Daerah. Selanjutnya, dalam pemeliharaan program tiket online ini masyarakat 


\section{Journal Publicuho}

ISSN2621-1351 (online), ISSN 2685-0729 (print)

Volume 4 Number 2 (May-July), (2021)pp. 360-370

Accredited SINTA SK.NOMOR 28/E/KPT/2019

Open Access at:http://ojs.uho.ac.id/index.php/PUBLICUHO/index

DOI: 10.35817/jpu.v4i2.17957

atau pengunjung berpendapat bahwa, jika mereka telah membeli atau memesan tiket secara online, maka secara tidak langsung masyarakat atau pengunjung juga ikut mendukung keberlanjutan program tiket online tersebut. Akan tetapi tidak semua masyarakat atau pengunjung dapat memahami secara aktif tentang perubahan pedoman yang akan terjadi dimasa mendatang.

\section{KESIMPULAN}

Berdasarkan uraian hasil penelitian yang telah dikemukakan, maka dapat ditarik kesimpulan sebagai berikut. Evidence informed policy pada program tiket online Taman Satwa Kebun Binatang Surabaya dapat dikatakan belum cukup optimal. Hal ini dikarenakan adanya:

1. Taman Satwa Kebun Binatang Surabaya secara aktif meningkatkan kesadaran dengan melibatkan pemangku kepentingan dan juga menggunakan jaringan mereka untuk menyebarkan kebijakan tersebut yaitu program tiket online. Tetapi tidak banyak masyarakat yang menyadari akan adanya interaksi yang dilakukan oleh Pemerintah dan Taman Satwa Kebun Binatang Surabaya.

2. Taman Satwa Kebun Binatang Surabaya juga memberikan penawaran khusus bagi pengunjung. Akan tetapi dalam hal ini masyarakat atau pengunjung masih belum mengetahui tentang adanya penawaran-penawaran yang dibuat oleh Taman Satwa Kebun Binatang Surabaya.

3. Strategi fasilitatif digunakan secara luas, dengan fokus pada pembentukan struktur pendukung untuk kebijakan program tiket online tersebut. Taman Satwa Kebun Binatang Surabaya menekankan komunikasi strategis dalam tahap implementasi, dan menekankan nilai setiap individu yaitu hak atas pelayanan yang mudah dan aman. Masyarakat atau pengunjung menganggap program tiket online ini menjadi keuntungan sendiri bagi setiap pengunjung.

4. Taman Satwa Kebun Binatang Surabaya mengatur pemeliharaan alat berbasis web yang berkualitas untuk terus mendukung penggunanya. Dalam hal ini jika masyarakat pengunjung telah membeli atau memesan tiket secara online, maka secara tidak langsung masyarakat atau pengunjung juga ikut mendukung keberlanjutan program tiket online tersebut. 


\section{REFERENSI}

Bowen S, Z. A. (2005). Pathways to "Evidence-Informed" Policy and Practice: A Framework for Action. PLoS Medicine.

Dinda, K. (2018). Aplikasi E-Ticketing Pariwisata Di Kabupaten Serang Berbasis Web. Seminar Nasional Rekayasa Teknologi Informasi.

Ibrahim, A. (201 1). Perancangan Sistem Pemesanan Tiket Pesawat Berbasis Web. Jurnal Sistem Informasi.

Ngadiyono, Y. (2010). Pemeliharaan Mekanik Industri. Yogyakarta: Kementrian Pendidikan Nasional Universitas Negeri Yogyakarta.

ODI. (2004). Does Evidence Matter? An ODI Meeting Series. London: ODI.

Panisset, U. (2012). Implementation Research Evidence Uptake and Use For Policy-Making. Bio Med Central.

Roihanah, D. (2017). Pengaruh Leisure Benefit Terhadap Kepuasan Pengunjung (Survey Pada Pengunjung Hawai Waterpark Malang). Jurnal Administrasi Bisnis.

Shaxson, L. (2005). Is Your Evidence Robust Enough? Questions For Polivy Makers And Practitioners' Evidence and Policy. A Journal of Research, Debade and Practice.

Strehlenert. (2015). Evidence-Informed Policy Formulation and Implementation: a Comparative Case Study of Two National Policies For Improving Health and Social Case In Sweden. Implementation Science.

Sugiyono. (2018). Metode Penelitian Kuantitaif, Kualitatif, dan R\&D. Bandung: Alfabeta.

Suharsaputra, U. (2018). Metode Penelitian (Kuantitatif, Kualitatif, dan Tindakan). Bandung: PT Refika Aditama.

Sukidin. (2019). Efektivitas Penerapan Mobile Application "KAl Access" Oleh Konsumen Kereta Api Indonesia Persero Daerah Operasi 9 Stasiun Jember. Pendidikan Ekonomi, 132.

Sukirno. (2006). Makro Ekonomi : Teori Pengantar. Jakarta: PT. Raja Grafindo Persada.

Supriadin, R., Alam, S., \& Elwan, L. O. M. (2020). IMPLEMENTASI PERATURAN WALIKOTA KENDARI NOMOR 13 TAHUN 2008 TENTANG PENATAAN PEDAGANG KAKI LIMA DI KOTA KENDARI. Journal Publicuho. https://doi.org/10.35817/jpu.v3i1.11506

Trachtman, S. (2020). What Drives Climate Policy Adoption in the U.S. state? Energy Policy. 138(January) 111214.

Wahyudi, A. (2016). Implementasi Rencana Strategis Badan Pemberdayaan Masyarakat Dan Desa Dalam Upaya Pengembangan Badan Usaha Milik Desa Di Kabupaten Kotawaringin Barat. Jurnal IImiah Administrasi Publik (JIAP).

https://www.afederasi.com/wisata/kebun-binatang-surabaya-re-opening-setelahpenutupan-sementara/

https://www.jawapos.com/surabaya/29/07/2020/buka-lagi-kebun-binatang-surabaya-kbsjadi-arena-belajar-new-normal/ 